\title{
Digital Platforms and Computer Utilization for Advertising
}

\author{
R Zulfikar1*, D R Ramadhan ${ }^{2}$ \\ ${ }^{1}$ Departemen Manajemen, Universitas Komputer Indonesia, Indonesia \\ 2Departemen Ilmu Komunikasi, Universitas Komputer Indonesia, Indonesia \\ Email: *rizki.zulfikar@email.unikom.ac.id
}

\begin{abstract}
The purpose of this research is to look at the business development strategies in the digital era through digital advertising promotion media. To support this research, we used descriptive method by analyzing digital advertising in social media to find a valid data and in accordance with the research conducted. The result of this research is that using digital advertising is more effective for the company as it is more appealing for the customers.
\end{abstract}

\section{Introduction}

With the rapid development of technology, almost all activities can be done using social. Therefore, it helps humans to do all their activities, especially in conducting their businesses. Soegoto stated that in order to be a successful entrepreneur, we must learn to get a broader insight about entrepreneurship [1]. Nowadays, almost everyone uses social media for their personal activities as well as doing a business. Therefore, social media has a great impact for human activities in the digital era. Social media is not only affecting a company, but, it also has expanded into education field and health. [2]. Social media is media that is used to extract data to solve problems that are understood by the customer base, especially for small and medium-sized businesses [3]. To build the originality of a trademark, it requires communication that can build consumer perceptions about a characteristic of a brand [4]. Previous studies stated that one strategy that can be used for marketing is to use social media, specifically for small businesses based on the Attention, Interest, Desire, and Action (AIDA) models. It serves as a guide for small business entrepreneurs on how to use social media strategically for marketing.

In addition, the concept of customer relationship management (CRM) as another strategy is to promote transactional and interactional relationships with customers to increase potential economic benefits such as brand loyalty. Other study also shows that the majority of 213 articles covering strong relationships between social media and branding show the importance of strategies to use social media to enhance product brands, such as co-branding or franchising [5-7]. Other research also shows that the use of social media is a necessity at this time, especially to access the data and information that can help in decision making and increase knowledge. With this technology, entrepreneurs can use various types of social 


\section{International Journal of Research and Applied Technology}

1(2)(2021) 227-231

Journal homepage: https://ojs.unikom.ac.id/index.php/injuratech

networking for entrepreneurship to communicate and transact with consumers. Besides, as a marketing medium through advertising brochures on the internet, it can help entrepreneur to provide information with low advertising costs about the product [8-10].

Based on the research case studies above, we can find out that social media is the most effective place to conduct a promotion in the current digital era. The purpose of this study is to look at business development strategies through social media in the field of community service. The method used in this study is descriptive method by analysing digital advertising in social media to find a valid data and in accordance with the research conducted.

\section{Method}

To support this study, we used descriptive method by by analysing digital advertising in social media to find a valid data and in accordance with the research conducted.

\section{Results and Discussion}

The development of technology and information is marked by the entry of the internet in human life that makes a significant change. With the development of technology, it makes many application platforms appear including social media. Social media are experiencing a rapid development. Therefore, social media is often used by businessman as a tool to promote their products (see Figure 1).

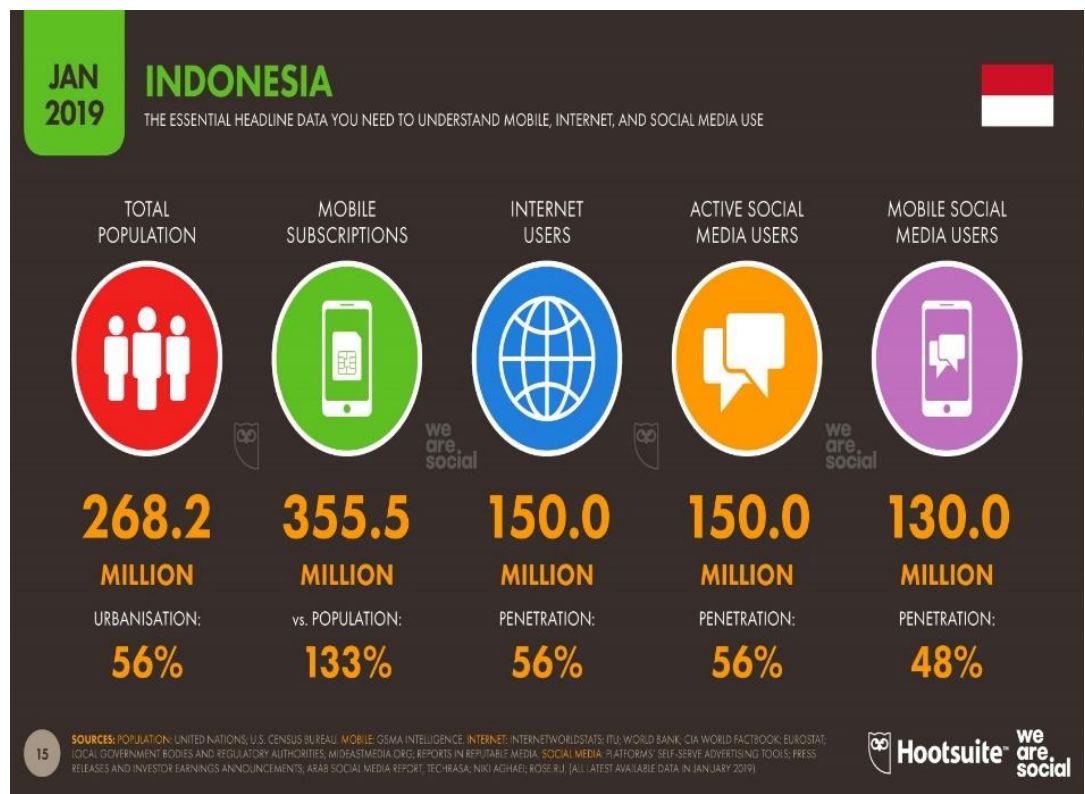

Figure 1. Data from internet and social media users in Indonesia on Jan 2019. This Figure was adopted from https://websindo.com/indonesia-digital-2019-tinjauanumum, on December 5, 2019

We can see from the figure above that the population in Indonesia reach 268 million with a percentage of $56 \%$. The total population of internet subscribers in Indonesia is 355.5 million with a percentage of $133 \%$. However, the total population of internet users is 150 million with a percentage of $56 \%$ and the number of active users on social media reaches 150 million users every day with a percentage of $56 \%$ and 130 million online users via mobile phones with a percentage of $48 \%$ (see Figure 2). 


\section{International Journal of Research and Applied Technology}

$1(2)(2021) 227-231$

Journal homepage: https://ojs.unikom.ac.id/index.php/injuratech

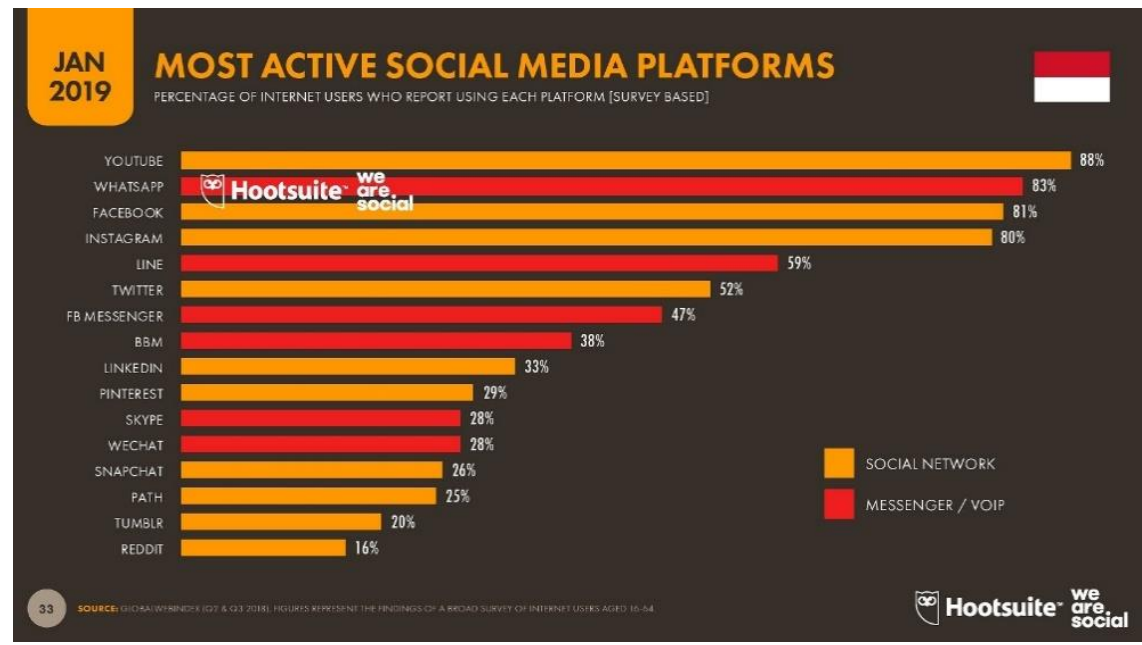

Figure 2. Social Media Data is most often used by internet users on Jan, 2019. This Figure was adopted from https:/ / websindo.com/indonesia-digital-2019-tinjauan-umum, on

December 5, 2019

Based on the data above, it shows that there are 5 social media that are most often used by internet users. The data is taken from the website WebSindo. The 5 media most frequently used by internet users in Indonesia in 2019 is YouTube, WhatsApp, Facebook, Instagram, Line with the percantage of $88,83,81,80$, and $59 \%$, respectively. From the statistics above, social media is needed by internet users. So, based on those needs, business activities that use social media as a forum for business start to emerge, especially social media Instagram as one of the most frequently used business platforms. Business is not only a non-profit business, but businesses in the health sector also use Instagram social media as a tool to promote their services (see Figure 3).

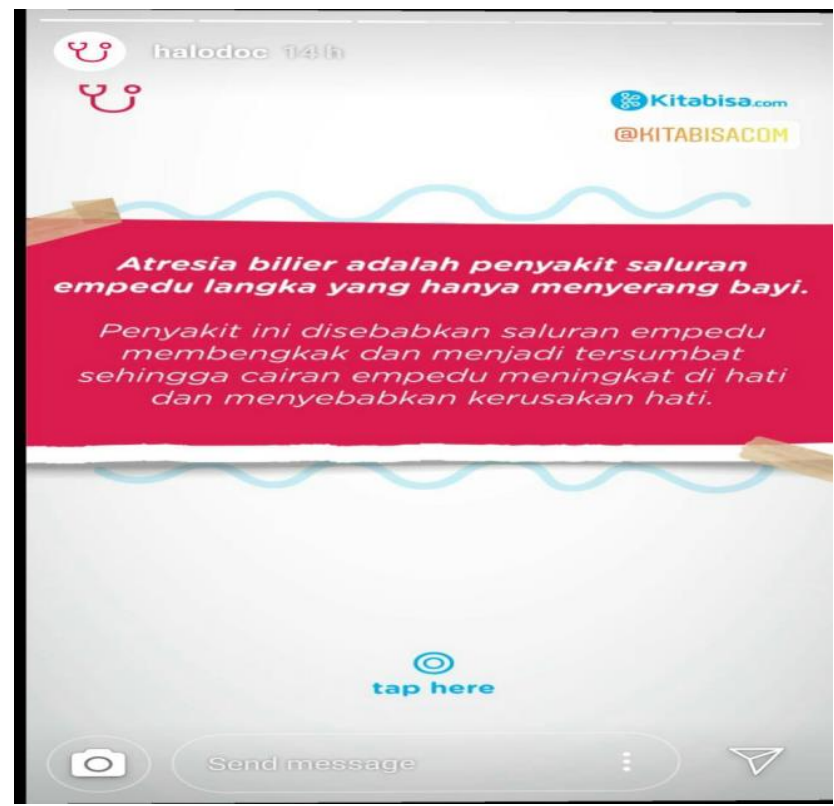

Figure 3. Instagram as a business and promotional media. This Figure was adopted from https://www.instagram.com/halodoc / stats?hl=en on 2019., on December 5, 2019 
One form of business activities carried out by companies engaged in the field of health could be seen in the figure photo above. It shows how the company provides an education about the disease as one of the interesting forms to spread the awareness (See Figure 4).

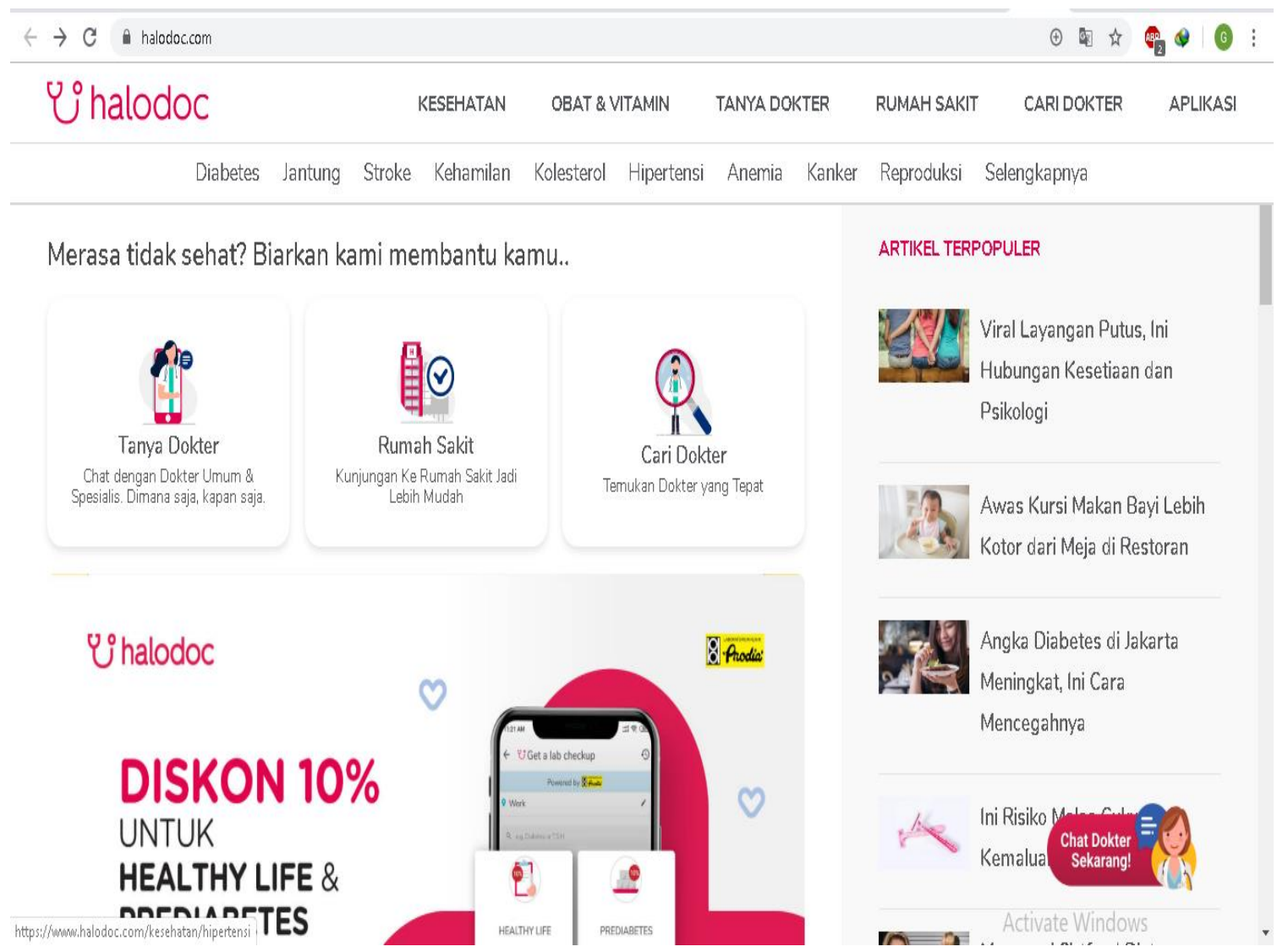

Figure 4. Website as one of the media promotion This Figure was adopted from http :/ /

halodoc.com., on December 5, 2019

\section{Conclusion}

In the figure 4, there is a tap here button so the users could go directly to the website, which contains more information about the company and features that can help to facilitate your needed, especially in the health sector on the website, namely:

1. Media information

Information menu about all diseases can be found on the website above and all menus about all kinds of drugs and doctors can be found.

2. Media transactions

The transaction menu on the company's website is located when a drug order procedure has been made or to make a doctor's appointment. With the menu button above, the company will understands what consumers want. 


\section{Acknowledgement}

It can be concluded that social media is one of the the tool to promote business better, especially business in the field of public health services. It is effective when it packed with new innovations. It will facilitate internet users to access and to maintain positive image for the company.

\section{References}

[1] Soegoto, E. S. 2014. Entrepreneurship Becomes a Revised Edition Businessman. Elex Media Komputindo. 45 (3), (pp. 80- 98).

[2] Soegoto, E. S., \& Utomo, A. T. 2019. Marketing Strategy Through Social Media. In IOP Conference Series: Materials Science and Engineering, 662(3), p. 032040.

[3] Puspitawati, L., Nurhasanah, A., \& Khaerunnisa, A. S. (2021). Utilization of Communication Technology for Business. International Journal of Informatics, Information System and Computer Engineering (INJIISCOM), 2(1), 47-54.

[4] Schivinski, B., \& Dabrowski, D. 2016. The effect of social media communication on consumer perceptions of brands. Journal of Marketing Communications, 22(2), pp. 189214.

[5] Hassan, S., Nadzim, S. Z. A., \& Shiratuddin, N. 2015. Strategic use of social media for small business based on the AIDA model. Procedia-Social and Behavioral Sciences, 172, pp. 262-269.

[6] Dewnarain, S., Ramkissoon, H., \& Mavondo, F. 2019. Social customer relationship management in the hospitality industry. Journal of Hospitality, 1(1), pp.1-14.

[7] Moro, S., \& Rita, P. 2018. Brand strategies in social media in hospitality and tourism. International Journal of Contemporary Hospitality Management, 30(1), pp. 343-364.

[8] Witteman, H. O., Fagerlin, A., Exe, N., Trottier, M. E., \& Zikmund-Fisher, B. J. 2016. Onesided social media comments influenced opinions and intentions about home birth: an experimental study. Health Affairs, 35(4), pp. 726-733.

[9] Sihite, B. J., \& Prihandini, A. 2019, Information Technology in Supporting Education World to Become an Entrepreneur. In IOP Conference Series: Materials Science and Engineering, 662(3), p. 032039).

[10] Soegotto, D. S., \& Istiqomah, A. O. 2019. E-brochure as a Communication Strategy in Entrepreneurship. In IOP Conference Series: Materials Science and Engineering, 662(3), p. 032038). 